\title{
The Prevalence of Aminoglycoside-Modifying Enzyme Genes Among Pseudomonas aeruginosa Strains Isolated From Burn Patients
}

\author{
Mojtaba Kashfi, ${ }^{1}$ Ali Hashemi, ${ }^{1}$ Gita Eslami, ${ }^{1,}$ Mehrzad Sadredin Amin, ${ }^{1}$ Samira Tarashi, ${ }^{1}$ and Elahe \\ Taki $^{2}$ \\ ${ }^{1}$ Department of Microbiology, School of Medicine, Shahid Beheshti University of Medical Sciences, Tehran, IR Iran \\ ${ }^{2}$ Department of Microbiology, Tehran University of Medical Sciences, Tehran, IR Iran \\ "Corresponding author: Gita Eslami, Department of Microbiology, School of Medicine, Shahid Beheshti University of Medical Sciences, Tehran, IR Iran. Tel: +98-2123872556, \\ E-mail: g_eslami@yahoo.com
}

Received 2016 July 17; Revised 2016 November 15; Accepted 2016 December 05.

\begin{abstract}
Background: The prevalence of resistance to aminoglycosides among $P$. aeruginosa isolates has increased all around the world. The resistance is caused through different mechanisms. One of these mechanisms is the use of enzymes such as phosphoryltransferases, acetyltransferases, and nucleotidyltransferases.

Objectives: The present study was conducted to determine the prevalence of $A p h\left(3^{\prime}\right)-I b, A p h\left(6^{\prime}\right)$-VI, rmtA, aac ( $\left.6^{\prime}\right)$-IIa, aadA, aadB, and $\operatorname{armA}$ genes among $P$. aeruginosa strains isolated from burn patients located in Tehran, Iran.

Methods: This descriptive study was performed on patients hospitalized at the Shahid Motahari burn hospital during August 2014 to July 2015. Antibiotic susceptibility tests were performed by disc diffusion and minimum inhibitory concentration methods. Aph ( $\left.3^{\prime}\right)$-Ib, Aph $\left(6^{\prime}\right)$-VI, $r m t A, a a c$ $\left(6^{\prime}\right)$-IIa, aadA, aadB, and armA genes were detected by PCR.

Results: 60 isolates were evaluated for antimicrobial susceptibility testing. The resistance of $P$. aeruginosa isolates to the tested antibiotics was as follows: 56 (94\%) to ciprofloxacin, 57 (95\%) to gentamicin, 57 (95\%) to Imipenem, 57 (95\%) to meropenem, 56 (94\%) to doripenem, 49 (82\%) to piperacillintazobactam, 58 (97.2\%) to amikacin, 45(75\%) to ceftazidime, 59(98\%) to Ticarcillin, 56 (93\%) to Cefepime, 54 (90\%) to piperacillin, 54 (90\%) to Aztreonam, and $0(0 \%)$ to colistin. Minimum inhibitory concentration (MIC) for amikacin and Gentamicin was determined according to the guidelines of CLSI. The highest resistance rate according to the MIC method was observed for Gentamicin and amikacin in 128 (40\%) and 256 (92\%) of the isolates, respectively. In this study, $94 \%$ of the isolates were multiple drug resistance (MDR). The prevalence of Aph $\left(3^{\prime}\right)$-Ib, Aph $\left(6^{\prime}\right)$-VI, rmtA, aac ( $\left.6^{\prime}\right)$-IIa, aadA, aadB, and $\operatorname{arm} A$ genes were $60 \%, 85 \%, 45 \%, 10 \%, 87.5 \%$, and $55 \%$ according to the PCR, method respectively.

Conclusions: This study detected multiple drug resistance (MDR) in P. aeruginosa including aminoglycosides. Therefore, identification of drug resistance patterns in $P$. aeruginosa is of great importance in prevention and control of infections in burn patient centers.
\end{abstract}

Keywords: P. aeruginosa, Multi Drug Resistance (MDR), Burn Patient, Aminoglycosides, Aminoglycoside-Modifying Enzymes

\section{Background}

Burn patients who have been hospitalized are at risk of being infected with multi drug resistant (MDR) bacteria including $P$. aeruginosa. These bacterium are amongst the important causes of Gram-negative infections, especially in burn patients. P. aeruginosa is the causative agent for a number of infections such as urinary tract infection (UTI), septicemia, endocarditis, pneumonia, skin, ears and eye infections and a leading cause of mortality amongst burn patients (1). P. aeruginosa is intrinsically resistant to a variety of antimicrobials $(2,3)$. The resistance of bacteria to antibiotics such as beta-lactams and aminoglycosides is increasing (4). Although the resistance typically results from drug inactivation by enzymes, enzyme-independent resistance is also common (5). The resistance enzymes are encoded by plasmids or chromosomes and may transfer to other species. Phosphorylation by aminoglycoside phosphoryltransferases (APHs), acetylation by aminoglycoside acetyltransferases (AACs), and adenylation by aminoglycoside nucleotidyltransferases (ANTs) or aminoglycoside adenylyltransferase (AAD) are mechanisms for enzymatic modification of aminoglycosides that lead to antibiotic inactivation $(5,6)$. The most important acetylation enzyme is aac $\left(6^{\prime}\right)$-IIa. This enzyme is the main cause of resistance to tobramycin, gentamicin, and Amikacin. $a p h\left(3^{\prime}\right)-I b$ is a phosphoryltransferase enzyme that causes resistance to kanamycin, neomycin, and streptomycin (7). $A N T\left(2^{\prime}\right)$-I enzyme is the most prevalent nucleotidyltransferase amongst $P$. aeruginosa isolates, which inactivates Gentamicin and Tobramycin but not amikacin (6). aadA and $a a d B$ genes encode ANT(3) and ANT(2) -I enzymes, respectively (6). Another mechanism for antibiotic inactivation is methylation of the $16 \mathrm{~S}$ rRNA of the A site of the 30S ribosomal subunit. This mechanism interferes with aminoglycoside binding and consequently leads to resistance to clinically relevant aminoglycosides like amikacin, gentamicin, and tobramycin (8). The aminoglycosidemodifying enzyme genes including rmtA and armA involve high-level aminoglycoside resistance with promoting $16 \mathrm{~S}$ 
rRNA methylases in P. aeruginosa $(9,10)$.

\section{Objectives}

The aim of this study was detection of $\operatorname{Aph}\left(3^{\prime}\right)$-Ib, $A p h\left(6^{\prime}\right)-V I, r m t A, \operatorname{aac}\left(6^{\prime}\right)$-IIa, aadA, aadB, and armA genes among $P$. aeruginosa strains isolated from burn patients hospitalized at Shahid Motahari hospital, Tehran, Iran during August 2014 to July 2015.

\section{Methods}

\subsection{Isolation and Clinical Identification}

This descriptive study was conducted on P. aeruginosa isolates collected during August 2014 to July 2015 from burn patients hospitalized at Shahid Motahari Hospital. Samples were collected by sterile swabs. Stuart media was used as transfer medium. Samples were cultured on MacConkey agar (Merck, Germany) and Cetrimide agar (Merck, Germany) and incubated at $37^{\circ} \mathrm{C}$ for 24 hours. Isolates of $P$. aeruginosa were detected by conventional laboratory tests such as oxidase test, catalase test, sugar fermentation test, and ability of growth in $42^{\circ}$ C. P. aeruginosa ATCC27853 was used as a control strain (11).

\subsection{Antimicrobial Susceptibility Testing}

Antimicrobial susceptibility to Imipenem (IPM, 10 $\mu \mathrm{g})$, Meropenem (MEM, $10 \mu \mathrm{g}$ ), ceftazidime (CAZ, $30 \mu \mathrm{g}$ ), amikacin (AK, $30 \mu \mathrm{g}$ ), piperacillin/tazobactam (PTZ, 100/10 $\mu \mathrm{g}$ ), ciprofloxacin (CIP, $5 \mu \mathrm{g}$ ), cefepime (FEP, $30 \mu \mathrm{g}$ ), aztreonam (ATM, $30 \mu \mathrm{g}$ ), gentamicin (GEN, $10 \mu \mathrm{g}$ ), doripenem (DOR, $10 \mu \mathrm{g}$ ), ticarcillin (TC, $30 \mu \mathrm{g}$ ), piperacillin (PRL, $100 \mu \mathrm{g})$, and colistin (CO, $10 \mu \mathrm{g}$ ) was performed by the Kirby-Bauer disk diffusion method on Mueller Hinton agar (Merck, Germany) based on the clinical and laboratory standards institute (CLSI) guidelines (12). P. aeruginosa ATCC27853 was used as a control strain.

\subsection{Minimum Inhibitory Concentration}

Minimum inhibitory concentration test was performed by microdilution broth method for two aminoglycosides (Amikacin and Gentamicin) according to the Clinical and Laboratory Standards Institute (CLSI) guidelines (11). P. aeruginosa ATCC27853 was used as a control strain.

\subsection{Detection of Aminoglycoside-Modifying Enzyme Genes}

Bacterium were cultured in LB (Luria Bertani) and were incubated overnight at $37^{\circ} \mathrm{C}$. Bacterial DNA was extracted by the standard DNA Extraction Kit (GeNet Bio, Korea, Cat. No K-3000). Polymerase chain reaction (PCR) amplification was performed for detection of $A p h\left(3^{\prime}\right)-I b, A p h\left(6^{\prime}\right)$ VI, rmtA, aac( $\left.6^{-}\right)$-IIa, aadA, aadB, and armA genes. The sequences of primer pairs used in the study are shown in Table 1.

Three $\mu \mathrm{L}$ of the extracted DNA $(100 \mathrm{ng} / \mu \mathrm{L})$ was added to a final volume of $25 \mu \mathrm{L}$ PCR mixture containing $12.5 \mu \mathrm{L}$ of 2 $\times$ Master Mix (Sinaclon- Iran, CAT. NO.: PR901638), including $1 \times$ PCR buffer, $0.08 \mathrm{IU}$ Taq DNA, $3 \mathrm{mmol} / \mathrm{L} \mathrm{MgCl}_{2}$ and $0.4 \mathrm{mmol} / \mathrm{L}$ dNTP polymerase, $1 \mu \mathrm{L}$ of $10 \mathrm{pmol} / \mathrm{L}$ from each primer, and $7.5 \mu \mathrm{L}$ of sterile distilled water.

PCR conditions included 36 cycles of amplification under the following conditions: Initiation Denaturation, 10 minutes at $94^{\circ} \mathrm{C}$, Denaturation at $94^{\circ} \mathrm{C}$ for 30 seconds, annealing for 1 minute at primer set specific temperatures (Table 1), and extension at $72^{\circ} \mathrm{C}$ for 1 minute. Cycling was followed by a final extension at $72^{\circ} \mathrm{C}$ for 10 minutes.

\subsection{Statistical Analysis}

MINITAB16 software was used for statistical analysis. The $\mathrm{P}$ value and confidence of intervals were $<0.05$ and $95 \%$, respectively.

\section{Results}

Sixty P. aeruginosa isolates were collected (47(78\%) from males and 13 (22\%) from females). The mean age was $36 \pm 1$. The resistance of $P$. aeruginosa isolates against tested antibiotics was as follows: 56 (94\%) to ciprofloxacin, 57 (95\%) to gentamicin, 57 (95\%) to imipenem, 57 (95\%) to Meropenem, 56 (94\%) to doripenem, 49 (82\%) to piperacillin-tazobactam, $105(97.2 \%)$ to amikacin, 45 (75\%) to ceftazidime, 59(98\%) to ticarcillin, 56 (93\%) to cefepime, $54(90 \%)$ to piperacillin, $54(90 \%)$ to aztreonam, and $0(0 \%)$ to colistin (Mast Group, merseyside, UK). Figure 1 shows the percentage of resistances by antibiotics resistance.

Prevalence of $A p h\left(3^{\prime}\right)-I b, A p h\left(6^{\prime}\right)-V I, r m t A, a a c\left(6^{\prime}\right)$-IIa, $\operatorname{aad} A, \operatorname{aadB}$, and $\operatorname{arm} A$ genes was $60 \%, 85 \%, 45 \%, 10 \%, 87.5 \%$, and 55\%, respectively (Figure 1 - 7).

\section{Discussion}

Antibiotic therapies are widely used for treating infectious diseases (16). Previous studies have indicated that $P$. aeruginosa is the most common bacterial isolate in burn wards in Tehran, Iran $(17,18)$. P. aeruginosa is resistant to 
Table 1. Oligonucleotide Sequences Used in the study

\begin{tabular}{|c|c|c|c|c|}
\hline Gene & Sequence & Amplicon Size, bp & Annealing Temperature $\left({ }^{\circ} \mathrm{C}\right)$ & References \\
\hline $\operatorname{arm} A-\mathbf{F}$ & TGGGAAGTTAAAGACGACGA & 212 & 55 & (13) \\
\hline $\operatorname{arm} A-\mathbf{R}$ & ССАТТСССТТСТССТТТССА & 212 & 55 & (13) \\
\hline rmtA-F & CTAGCGTCCATCCTTTCСTC & 635 & 55 & (9) \\
\hline rmtA-R & TTTGCTTCCATGCCCTTGCC & 635 & 55 & (9) \\
\hline $\operatorname{Aph}\left(3^{\prime}\right)-I b \mathrm{~F}$ & CTTGGTGATAACGGCAATTCC & 548 & 55 & In this study \\
\hline $\operatorname{Aph}\left(3^{\prime}\right)-I b \mathrm{R}$ & CCAATCGCAGATAGAAGGCAA & 548 & 55 & In this study \\
\hline $\operatorname{Aph}\left(6^{\prime}\right)-V I F$ & AGCGAAAATGTTGAGTTGGCT & 399 & 60 & (14) \\
\hline $\operatorname{Aph}\left(6^{\prime}\right)-V I R$ & TCCGTGATATCGCCATGAGA & 399 & 60 & (14) \\
\hline aadA1-F & ATGAGGGAAGCGGTGATCG & 320 & 55 & (14) \\
\hline aadA1-R & TTATTTGCCGACTACCTTGGTG & 320 & 55 & (14) \\
\hline aadB-F & ATGGACACAACGCAGGTCGC & 120 & 55 & (14) \\
\hline aadB-R & TTAGGCCGCATATCGCGACC & 120 & 55 & (14) \\
\hline $\operatorname{aac}(6) \operatorname{IIa}-\mathrm{F}$ & CCATAACTCTTCGCCTCATG & 542 & 52 & (15) \\
\hline $\operatorname{aac}(6)$ IIa $-\mathrm{R}$ & GAGTTGTTAGGCAACACCGC & 542 & 52 & (15) \\
\hline
\end{tabular}

Table 2. Assessment of resistance to Amikacin and Gentamicin in the MIC ( $\mu \mathrm{g} / \mathrm{mL})$ Method

\begin{tabular}{lccccccc}
\hline Antibiotic, $\mu \mathbf{g} / \mathbf{m L}$ & $\mathbf{2}$ & $\mathbf{4}$ & $\mathbf{8}$ & $\mathbf{1 6}$ & $\mathbf{3 2}$ & $\mathbf{6 4}$ & $\mathbf{2 5 6}$ \\
\hline Gentamicin & 0 & 0 & $1(1.7)$ & $1(1.7)$ & $5(8.3)$ & $6(10)$ & $24(40)$ \\
Amikacin & $3(5)$ & 0 & 0 & 0 & 0 & 0 & $2(3.3)$ \\
\hline
\end{tabular}

\section{Figure 1. Antibiotics Resistance}

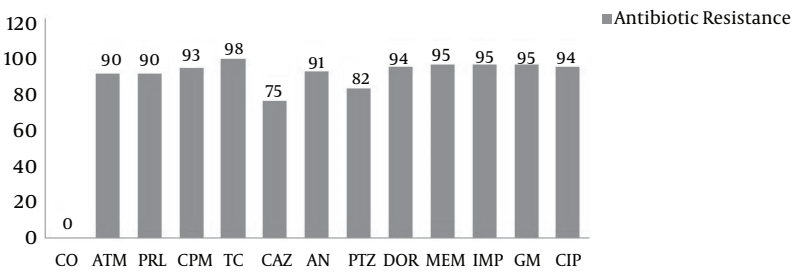

Abbreviations: CO, colistin; ATM, aztreonam; PRL, piperacillin; TC, ticarcillin; CAZ, ceftazidime; AN, amikacin; PTZ, piperacillin-tazobactam; DOR, doripenem; MEM, meropenem; IMP, imipenem; GM, gentamicin; CIP, ciprofloxacin. Highest amount of resistance in MIC for gentamicin was 256 (38\%). While highest amount of resistance in MIC for Amikacin was 32 (70\%) (Table 2).

a range of antibiotics such as Beta-lactams and aminoglycosides (19). Aminoglycoside resistance in P. aeruginosa is often associated with the production of various enzymes $(5,6)$. This resistance has become a worldwide problem (20), especially in Asia (21). According to disk diffusion results $94 \%$ of the isolates were resistant to ciprofloxacin and $75 \%$ were resistance to ceftazidime. Also $66.6 \%$ of the isolates were detected as multi-drug resistant (MDR), which shows that the resistance rate has increased in comparison with other studies. Results of a study done in Yazd, Iran during 2013 showed the most resistance rate was seen

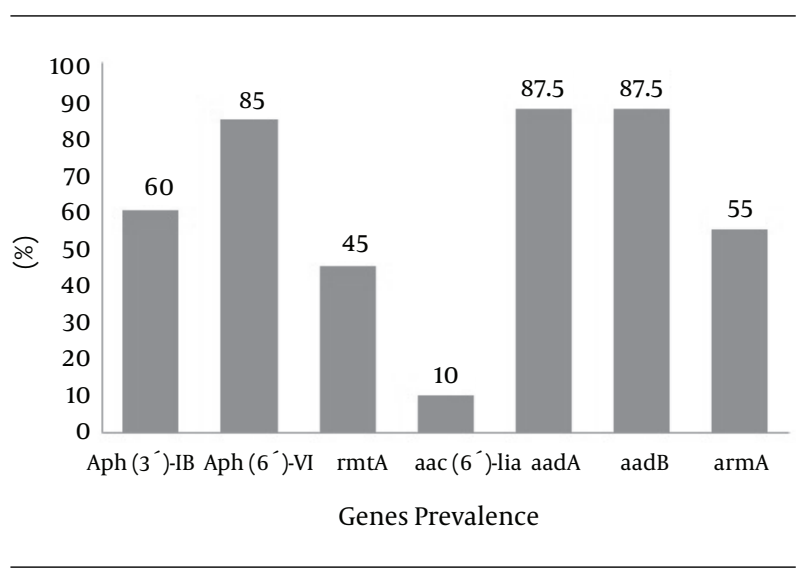

Figure 2. The Incidence of Aminoglycoside Resistance Genes

for ceftazidime, in that $56 \%$ of the isolates were resistant to this antibiotic. In the same study the resistance rate to Ciprofloxacin was $44.4 \%$ and $94 \%$ of the isolates were detected as multi-drug resistant (MDR) (18). In a study done in Tehran, Iran, the resistance rate was $43 \%$ for Gentamicin and $24 \%$ for amikacin (22), which is lower in comparison with our study. These reports are in contrary with the result of our study, in which Gentamicin and Amikacin resistances rates among $P$. aeruginosa isolates from wound infections were 95\% and 91\%, respectively. Limitations in phe- 
Figure 3. PCR Amplification of $A p h\left(6^{\prime}\right)-V I$ Gene Amongst P. aeruginosa

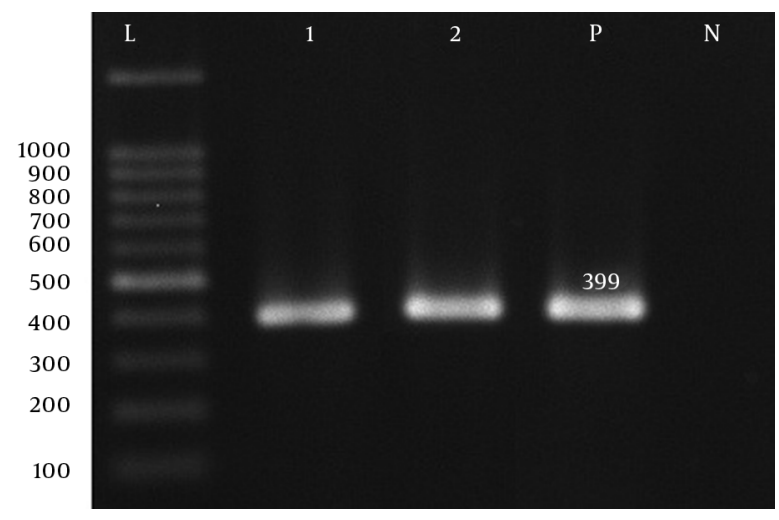

L, 100 bp DNA size marker; P, positive control; N, negative control, 1 and 2 clinical positive isolates.

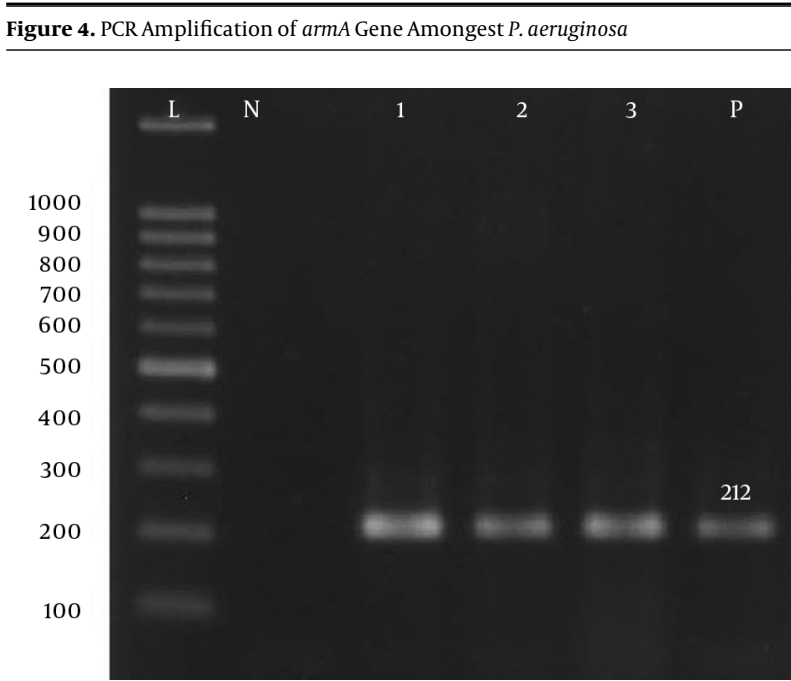

L, 100 bp DNA size marker; P, positive control; N, negative control, 1, 2 and 3 clinical positive isolates.

notypic methods make researchers confirm phenotypic results by molecular methods. In the present study, the aadA, $a a d B$ and $A p h\left(6^{\prime}\right)$-VI genes were more prevalent than the $\operatorname{armA}, A p h\left(3^{\prime}\right)$-Ib and $\operatorname{aac}\left(6^{\prime}\right)$-IIa genes amongst $P$. aeruginosa isolates of burn patients. This prevalence of genes in our study showed an increasing trend of resistance in comparison to previous years. In a study from France, $1.9 \%$ of isolates were positive for the $\operatorname{aac}\left(6^{\prime}\right)$-II a gene in 2008 (15) while in our study, $10 \%$ of the isolates were positive for the $\operatorname{aac}\left(6^{\prime}\right)$-IIa gene. PCR results for aminoglycoside resistance methyltransferase (21) gene was negative in Tehran during 2011 (23). In a study from China, armA was detected in $22 \%$ of $P$. aeruginosa strains (24). While in the present study,

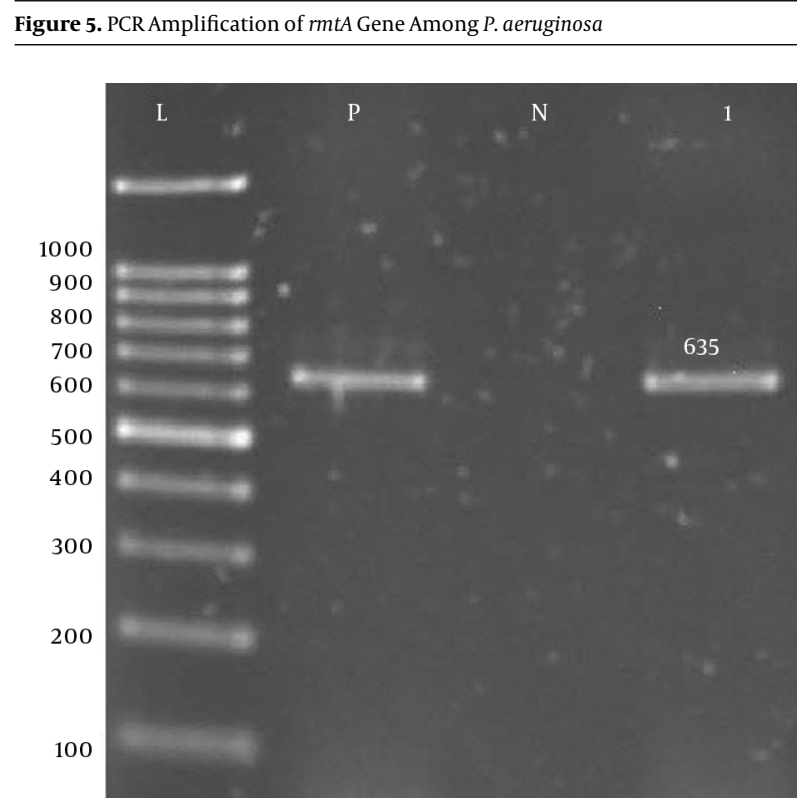

L, 100 bp DNA size marker; P, positive control; N, negative control, 1 clinical positive isolate.

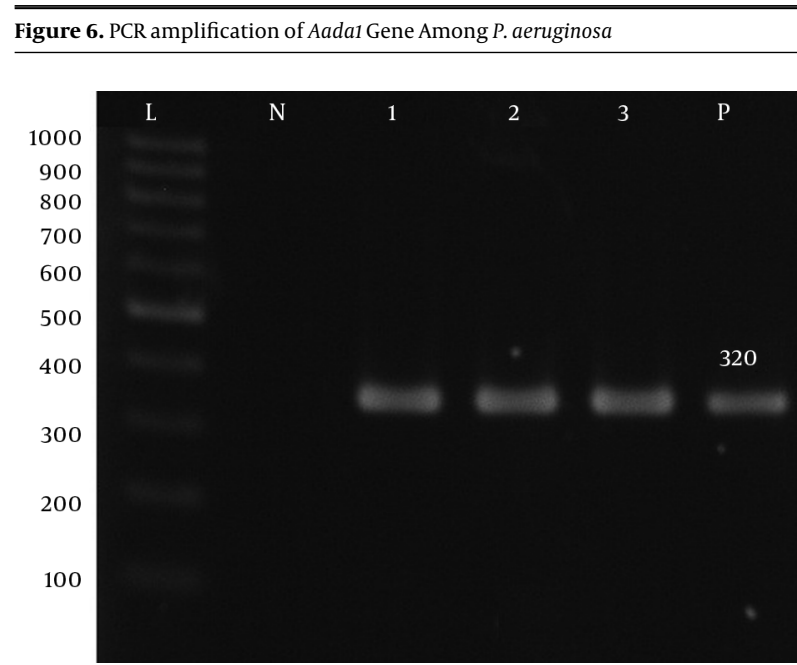

L, 100 bp DNA size marker; P, positive control; N, negative control, 1, 2 and 3 clinical positive isolates.

$\operatorname{armA}$ was detected in $55 \%$ of isolates. Prevalence of Aph $\left(3^{\prime}\right)$ $I b, A p h(6-V I)$, aadA, and $a a d B$ genes were $60 \%, 85 \%, 87.5 \%$, and $87.5 \%$, respectively. In other countries, the prevalence of the genes were different. In a study from Poland, the prevalence of $A p h\left(3^{\prime}\right)$-Ib gene was 8.0\% (20). In another study from Nigeria, $\operatorname{arc}\left(6^{\prime}\right)$-IIa and $\operatorname{ant}\left(2^{\prime \prime}\right)$-I were found in 12 isolates out of 54 (18.5\%). Also in our study, none of the isolates were positive for the $A p h\left(3^{\prime}\right)$-Ib and $\operatorname{aac}\left(6^{\prime}\right)$-II a genes (25). Therefore, control and treatment of these infections 
Figure 7. PCR Amplification of aadB Gene Among P. aeruginosa

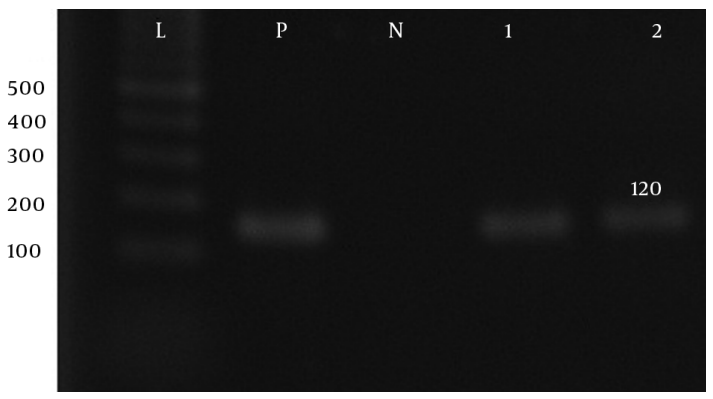

L, 100 bp DNA size marker; P, positive control; N, negative control, 1 and 2 clinical positive isolates.

caused by P. aeruginosa is complex, there is a need for revise treatment protocols to prevent resistant genes dissemination amongst clinical isolates.

\section{Acknowledgments}

This work was financially supported by the Shahid Beheshti University of Medical Sciences, Tehran, Iran.

\section{References}

1. Heidary M, Hashemi A, Goudarzi H, Khoshnood S, Roshani M, Azimi $\mathrm{H}$. The antibacterial activity of Iranian plants extracts against metallo beta-lactamase producing Pseudomonas aeruginosa strains. J Paramed Sci. 2016;7(1).

2. Park YS, Lee H, Chin BS, Han SH, Hong SG, Hong SK, et al. Acquisition of extensive drug-resistant Pseudomonas aeruginosa among hospitalized patients: risk factors and resistance mechanisms to carbapenems.J Hosp Infect. 2011;79(1):54-8. doi:10.1016/j.jhin.2011.05.014. [PubMed: 21764173].

3. Tadvi J, Javadekar T, Bhavsar R, Garala N. Prevalence \& antibiogram of Pseudomonas aeruginosa at SSG Hospital, Baroda, Gujarat, India.J Res Med Dental Sci. 2015;3(3):204-7. doi:10.5455/jrmds.20153310.

4. Hashemi A, Fallah F, Erfanimanesh S, Chirani AS, Dadashi M. Detection of Antibiotic Resistance Genes among Pseudomonas aeruginosa Strains Isolated from Burn Patients in Iran. British Microbiol Res J. 2016;12(4):1-6.

5. Poole K. Pseudomonas aeruginosa: resistance to the max. Front Microbiol. 2011;2:65. doi: 10.3389/fmicb.2011.00065. [PubMed: 21747788].

6. Poole K. Aminoglycoside resistance in Pseudomonas aeruginosa. Antimicrob Agents Chemother. 2005;49(2):479-87. doi: 10.1128/AAC.49.2.479-487.2005. [PubMed: 15673721].

7. Ramirez MS, Tolmasky ME. Aminoglycoside modifying enzymes. Drug Resist Updat. 2010;13(6):151-71. doi: 10.1016/j.drup.2010.08.003. [PubMed: 20833577].

8. Doi Y, Arakawa Y. $16 \mathrm{~S}$ ribosomal RNA methylation: emerging resistance mechanism against aminoglycosides. Clin Infect Dis. 2007;45(1):88-94. doi:10.1086/518605. [PubMed: 17554708].

9. Yamane K, Doi Y, Yokoyama K, Yagi T, Kurokawa H, Shibata N, et al. Genetic environments of the rmtA gene in Pseudomonas aeruginosa clinical isolates. Antimicrob Agents Chemother. 2004;48(6):2069-74. doi: 10.1128/AAC.48.6.2069-2074.2004. [PubMed: 15155201].
10. Zhou Y, Yu H, Guo Q, Xu X, Ye X, Wu S, et al. Distribution of $16 \mathrm{~S}$ rRNA methylases among different species of Gram-negative bacilli with high-level resistance to aminoglycosides. Eur J Clin Microbiol Infect Dis. 2010;29(11):1349-53. doi: 10.1007/s10096-010-1004-1. [PubMed: 20614151].

11. Wayne P. Clinical and Laboratory Standards Institute (CLSI) performance standards for antimicrobial disk diffusion susceptibility tests. 2015.

12. Jorgensen JH, Ferraro MJ. Antimicrobial susceptibility testing: a review of general principles and contemporary practices. Clin Infect Dis. 2009;49(11):1749-55. doi:10.1086/647952. [PubMed: 19857164].

13. Aghazadeh M, Rezaee MA, Nahaei MR, Mahdian R, Pajand O, Saffari $F$, et al. Dissemination of aminoglycoside-modifying enzymes and 16S rRNA methylases among acinetobacter baumannii and Pseudomonas aeruginosa isolates. Microb Drug Resist. 2013;19(4):282-8. doi: 10.1089/mdr.2012.0223. [PubMed: 23577624].

14. Asadollahi P, Akbari M, Soroush S, Taherikalani M, Asadollahi $\mathrm{K}$, Sayehmiri $\mathrm{K}$, et al. Antimicrobial resistance patterns and their encoding genes among Acinetobacter baumannii strains isolated from burned patients. Burns. 2012;38(8):1198-203. doi: 10.1016/j.burns.2012.04.008. [PubMed: 22579564].

15. Dubois V, Arpin C, Dupart V, Scavelli A, Coulange L, Andre C, et al. Beta-lactam and aminoglycoside resistance rates and mechanisms among Pseudomonas aeruginosa in French general practice (community and private healthcare centres).J Antimicrob Chemother. 2008;62(2):316-23. doi:10.1093/jac/dkn174. [PubMed: 18467306].

16. Chatterjee M, Anju CP, Biswas L, Anil Kumar V, Gopi Mohan C, Biswas R. Antibiotic resistance in Pseudomonas aeruginosa and alternative therapeutic options. Int J Med Microbiol. 2016;306(1):48-58. doi: 10.1016/j.ijmm.2015.11.004. [PubMed: 26687205].

17. Rastegar Lari AR, Alaghehbandan R, Akhlaghi L. Burn wound infections and antimicrobial resistance in tehran, iran: an increasing problem. Ann Burns Fire Disasters. 2005;18(2):68-73. [PubMed: 21990981].

18. Kiani M, Zandi H, Astani A, Vakili M, Musavi M, Zarei M. Investigating Antibiotic Resistance in Pseudomonas Aeruginosa Strains Isolated from Various Clinical Specimens of Patients Referring to Hospitals in Yazd. J Shahid Sadoughi Uni Med Sci. 2015;22(6):1644-53.

19. Goudarzi H, Taherpour A, Fallah F, Pourkaveh B, Erfanimanesh S, Hashemi A. Laboratory Detection of Carbapenemases in GramNegative Bacteria. Arch Clin Infect Dis. 2016;inpress(inpress) doi: 10.5812/archcid.32816.

20. Michalska AD, Sacha PT, Ojdana D, Wieczorek A, Tryniszewska E. Prevalence of resistance to aminoglycosides and fluoroquinolones among Pseudomonas aeruginosa strains in a University Hospital in Northeastern Poland. Braz J Microbiol. 2014;45(4):1455-8. doi: 10.1590/S151783822014000400041. [PubMed: 25763054].

21. Bhatt P, Rathi KR, Hazra S, Sharma A, Shete V. Prevalence of multidrug resistant Pseudomonas aeruginosa infection in burn patients at a tertiary care centre. India J Burns. 2015;23(1):56. doi: 10.4103/0971653X.171656.

22. Vaziri F, Peerayeh SN, Nejad QB, Farhadian A. The prevalence of aminoglycoside-modifying enzyme genes (aac (6')-I, aac (6')-II, ant (2")-I, aph (3')-VI) in Pseudomonas aeruginosa. Clinics (Sao Paulo). 2011;66(9):1519-22. [PubMed: 22179152].

23. Jafari M, Fallah F, Borhan RS, Navidinia M, Karimi A, Tabatabaei SR. The first report of CMY, aac $\left(6^{\prime}\right)$-Ib and 16S rRNA methylase genes among Pseudomonas aeruginosa isolates from Iran. Arch Pediatr Infect Dis. 2013;1(3):109-12. doi:10.5812/pedinfect.11392.

24. Li J, Zou M, Dou Q, Hu Y, Wang H, Yan Q, et al. Characterization of clinical extensively drug-resistant Pseudomonas aeruginosa in the Hunan province of China. Ann Clin Microbiol Antimicrob. 2016;15(1):35. doi: 10.1186/s12941-016-0148-y. [PubMed: 27215335].

25. Odumosu BT, Adeniyi BA, Chandra R. Occurrence of aminoglycosidemodifying enzymes genes ( $\mathrm{aac}\left(6^{\prime}\right)-\mathrm{I}$ and ant(2")-I) in clinical isolates of Pseudomonas aeruginosa from Southwest Nigeria. Afr Health Sci. 2015;15(4):1277-81. doi: 10.4314/ahs.v15i4.29. [PubMed: 26958031] 